\title{
Population status of the American crocodile, Crocodylus acutus (Reptilia: Crocodilidae) and the caiman, Caiman crocodilus (Reptilia: Alligatoridae), in the Central Caribbean of Costa Rica
}

\author{
Juan Rafael Bolaños Montero ${ }^{1 *}$, Juan José Sánchez Ramírez ${ }^{1}$, Luis Sigler ${ }^{2}$, Brady Robert Barr ${ }^{3}$ \\ \& Iván Sandoval Hernández ${ }^{4}$ \\ 1. Asociación de Profesionales en Crocodílidos (ASOPROCROC), 41001 3069, Heredia, Puerto Viejo de Sarapiquí; \\ asoprocroc@gmail.com \\ 2. Dallas World Aquarium Zoo (DWAZoo), 1801. N. Griffin. Dallas. Texas. USA; luis@dwazoo.com \\ 3. Ecoadventures, Severna Park, MD, 21146, USA; drbrabybarr@gmail.com \\ 4. Escuela de Ciencias Biológicas, Universidad Nacional, 40101 3020, Heredia, Costa Rica; \\ ivan.sandoval.hernandez@una.ac.cr \\ * Correspondence
}

Received 29-X-2018. Corrected 05-VIII-2019. Accepted 11-IX-2019.

\begin{abstract}
Two species of crocodilians have been described in Costa Rica, American crocodile, Crocodylus acutus (Cuvier, 1807), and caiman, Caiman crocodilus (Linnaeus 1758). In Costa Rica, data has been generated on both species, but populations in the Pacific have received more attention from researchers; presumably due to the fact that the Pacific slope has a greater development, which brings greater social pressure on the attention of the incidents generated by the encounter between humans and crocodiles. This study, performed during 2017, was done in an area of approximately $400 \mathrm{~km}^{2}$, characterized by having a wide and dense network of water courses, which includes the Matina, Pacuare, Reventazón and Parismina rivers. In these rivers, an average of 25 kilometers were traveled from the coastline up stream to the interior of the territory, including the Tortuguero canals, and other water bodies that connect these rivers, as well as in the most important lagoons and secondary channels. Three repetitions were made per segment. A population of 1084 caimans and 503 crocodiles is estimated; for a sight count of 8.64 and $2.80 \mathrm{ind} / \mathrm{Km}$ respectively. Speaking of caimans, up to $12 \%$ of individuals of reproductive age were observed, while for crocodiles that number was only $2 \%$. The abundance of both species in the different places studied, turned out to be significantly different for crocodiles and for caimans (Kruskal-Wallis, $\mathrm{P} \leq 0.001$ ). Likewise, the size distribution is similar for crocodiles reported in all environments (Kruskal-Wallis, $\mathrm{p} \leq 0.15$ ), while for caimans it indicates that there is a different distribution for sizes, according to the environment in which they are found (Kruskal -Wallis, $\mathrm{P} \leq 0.001$ ), with a bias against of the Pacuare and Matina rivers. It was possible to estimate a sex ratio of 1.25 and 0.83 males to females, in crocodiles and caimans respectively, with 9 and 11 captures in that same order, in recruit and juvenile sizes.
\end{abstract}

Key words: Crocodylus acutus, Caiman crocodilus, Costa Rica, Central Caribbean, crocodilian population status, Tortuguero Channels.

Bolaños Montero, J. R., Sánchez Ramírez, J. J., Sigler, L., Barr, B. R. \& Sandoval Hernández, I. (2019). Population status of the American crocodile, Crocodylus acutus (Reptilia: Crocodilidae) and the caiman, Caiman crocodilus (Reptilia: Alligatoridae), in the Central Caribbean of Costa Rica. Revista de Biología Tropical, 67(6), 1180-1193.

Two species of crocodilians have been described in Costa Rica: the American crocodile (Crocodylus acutus, Cuvier 1807), and the spectacled caiman (Caiman crocodilus,
Linnaeus 1758). The caiman is reported in the Atlantic slope, Northern Zone, Central Pacific and South Pacific, in continental freshwater of low flow, lagoons and streams. On the other 
hand, the crocodile inhabits the coasts of both slopes, including the North Zone, up to a height of $700 \mathrm{~m}$ above sea level, its habitat can be both, brackish (estuarine) and freshwater, and shows high tolerance to salt water (King, Espinal, \& Cerrato, 1990; Sánchez, Bolaños, \& Piedra, 1996; Bolaños, Sánchez, \& Piedra, 1996; Ross, 1998; Sánchez, 2001; Bolaños, 2011a; Bolaños, 2011b; Bolaños, 2012a; Bolaños, 2012b; Orozco, 2015; Sandoval-Hernández, Durán-Apuy, \& Quirós-Valerio, 2017).

In Costa Rica, data has been generated on both species, directed mostly towards population estimates and counting the number of individuals per area, mainly in the Caño Negro Wildlife Refuge (Allsteadt \& Vaughan, 1988; Sánchez, 1991); Río Grande de Tárcoles in the Carara Biological Reserve (Sasa \& Chaves, 1992; Torrealba, Paz, \& Motte, 1992); in the Gulf of Nicoya, Sierpe-Térraba, La Rambla (Bolaños, Sánchez, \& Piedra, 1996-1997); Tempisque-Bebedero River (Sánchez, Bolaños, \& Piedra, 1996); Grande de Tárcoles, Tulín and Jesús María (Piedra, 2000) and Tempisque river (Sánchez, 2001; Bolaños, 2012a; Orozco, 2015).

Different from crocodile populations of the North Zone and Caribbean Slope, the populations of it in the Costa Rican Pacific slope have received much more attention from researchers; this could be so, possibly due to the fact that the Pacific slope has a greater development, which brings greater social pressure on the attention of the incidents generated by the encounter between humans and crocodiles (Valdelomar et al., 2012; Sandoval-Hernández, Durán-Apuy, \& Quirós-Valerio, 2017).

In the Caribbean Slope, it has been observed that wild species use to keep distance from humans, specifically crocodilians, which does not necessarily mean that conflicts between humans and crocodiles do not occur, but that in most of the cases the report does not transcend the same in the news (Bolaños, 2012a; Bolaños, 2011b). The analysis of the situation in the area demonstrates the existence of an underlying problem in the human-crocodile relationship, where it is possible to quantify at least 10 fatal encounters registered since 1997 (Bolaños, 2012a; Bolaños, 2012b), not to mention non-fatal ones, whose report receives even less attention. Due to the previous reasons, it was decided to diagnose the status of the populations of the American crocodile and the caiman, in the Central Caribbean of Costa Rica; precisely in the lower basin of the Matina, Pacuare, Reventazón and Parismina rivers, and the coastal channel (segment of the Tortuguero canals) that intercommunicates them.

\section{MATERIALS AND METHODS}

Study area: After spending six months arranging the factors related to physical positioning in the terrain, the design of the routes to be carried out, as well as the necessary administrative coordination and the lifting of the necessary budget, the field part of the research was conducted during 2017 in the Central-North Caribbean of Costa Rica, province of Limón, in the area identified with the highest number of reports of incidents with crocodilians.

The study was done in an area of approximately $400 \mathrm{~km}^{2}$, characterized by having a wide and dense network of water courses, which includes the Matina, Pacuare, Reventazón and Parismina rivers. In these rivers. An average of 25 kilometers were traveled from the coastline up stream to the interior of the territory, plus the Tortuguero canals, and other water bodies that connect these rivers, as well as in the most important lagoons and secondary channels.

Three repetitions of the night sighting counts were made during different times of the year, to the three rivers in the study and the Jalova Lagoon, which were thought as the most important and representative segments of the whole area. Two repetitions were devoted to the three intercommunicating segments of the Tortuguero Channels; to the segment which joins the Caño Blanco bus terminal, by the Reventazón river, with the Parismina town; and the Caño Pascual segment, thinking of them as secondary in use for the crocodilians, given the constant presence of humans. Lastly, the other small segments were checked only once, owed 


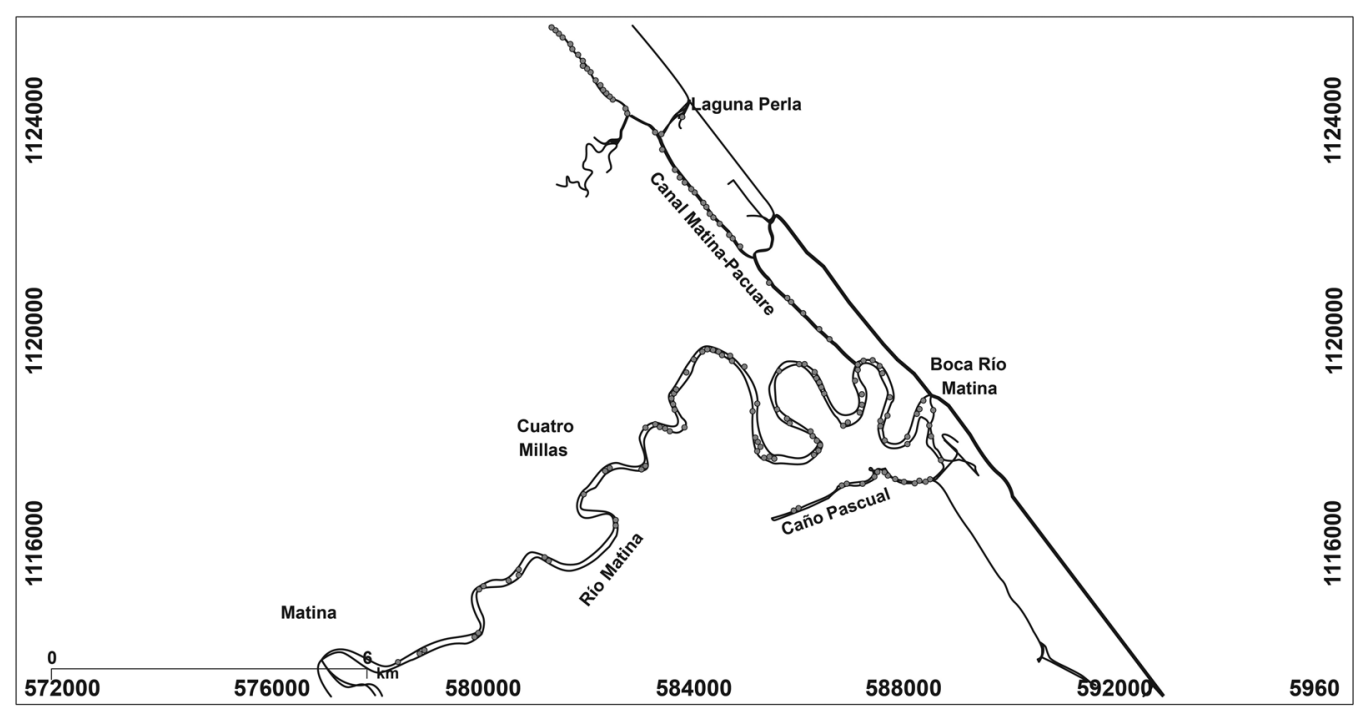

Fig. 1. Sub-área 1: Matina.

to their small length, and that during the first visit almost none animals were sighted.

A total of thirteen segments were surveyed during this study, known here as Reventazón river (29 km, three repetitions), Pacuare river (17 km, three repetitions), Matina river $(25 \mathrm{~km}$, three repetitions), Jalova Lagoon ( $2.2 \mathrm{~km}$, three repetitions), Caño California (6.5, two repetitions), Jalova-Reventazón Channel (5.8 km, two repetitions), Caño Pascual (6.5 km, two repetitions), Caño Blanco-Parismina (5.5 km, two repetitions), Pacuare-Reventazón Channel (8.5 $\mathrm{km}$, two repetitions), Pacuare-Matina Channel (13.75 km, two repetitions), Caldera Lagoon (3 $\mathrm{km}$, one repetition), Caño Chiquero $(1.2 \mathrm{~km}$, one repetition) and Perla Lagoon $(1.7 \mathrm{~km}$, one repetition) (Fig. 1, Fig. 2 and Fig. 3). Red dots represent georeferentiated observations).

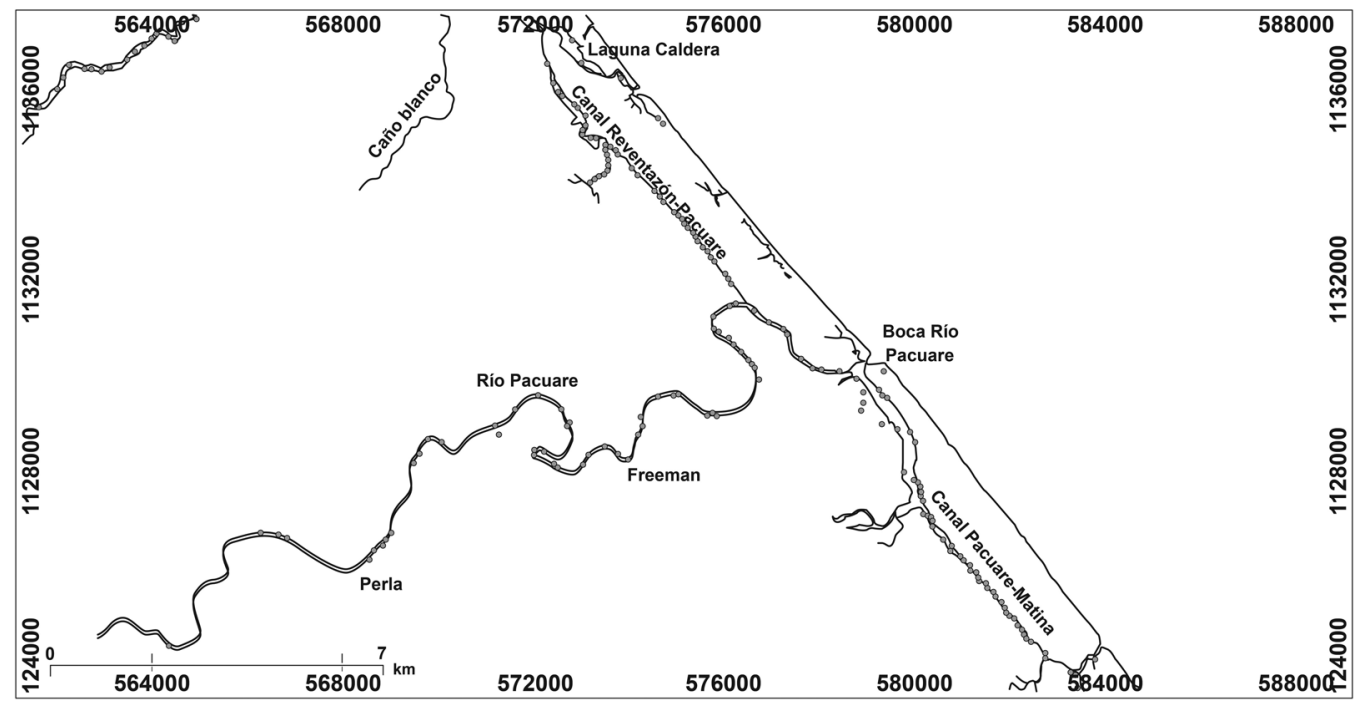

Fig. 2. Sub-área 2: Pacuare. 


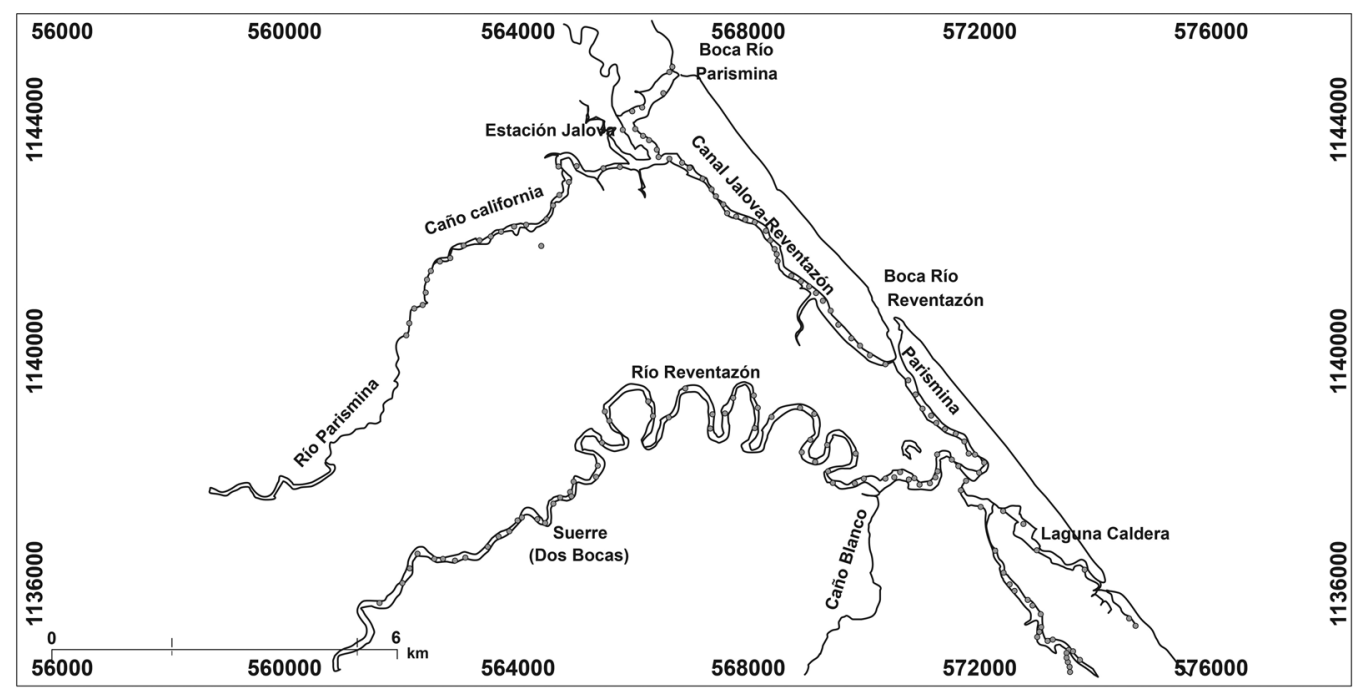

Fig. 3. Sub-área 3: Reventazón - Parismina.

Three basic kinds of environment are found among these segments, characterized by the rivers themselves, with strong currents and some human transit, since they are used commonly as communicating ways; the Tortuguero Channels, which are the small channels communicating the rivers among them and with the Limon city to the South and to Barra del Colorado to the North, these are deep channels with a relatively high boat transit, since it is the usual way tourists use to move along the coast; lastly, there is the more swampy, weedy, and deep and quiet waters of the secondary channels and small lagoons, with just sporadic human presence.

Sighting counts and population structure: To collect the data, night counts were carried out during the period between January and December. Each visit consisted of three days and two nights of effective work, devoting one night per segment every time. Monitoring always took place during the new moon phase, to ensure the maximum possible environmental darkness, and maximize the opportunity to sight and capture. Nocturnal counts were made using 6-volt LED head lamps and up to 8000 lumens, which illuminates the environment and determines the location of the crocodilians present, taking advantage of the animal's eye reflection (Levy, 1981).

The sizes of the crocodilians sighted were estimated provided the maximum posible approximation to the animal and under the following parameters: a) estimating the distance between the eyes and the tip of the snout, b) estimating the distance between the eyes, c) direct estimation (full appreciation) of the total length of the animal), d) those animals that submerge before being able to observe their size, were defined as "undeterminate", and joined the general group of crocodilians counted, without concrete size or species allocation (Bolaños, Sánchez, \& Piedra, 1996-1997).

Counting and size estimation tours were programmed in which no animals were captured; and there were also tours only to capture, in order to collect information that would allow to estimate the sex ratio and the placement of identification microchips in the captured individuals (Bolaños, 2012b). The tours were made using an inflatable boat of $6 \mathrm{~m}$ length and $1.5 \mathrm{~m}$ width, and a $18 \mathrm{HP}$ short leg outboard engine. The work in the boat was always developed by no more than two researchers, due to the limited space in the boat for the 
hauling of the minimum necessary equipment, and for the maneuver during the capture and handling of animals.

Capture, measurement, marking and identification: Whenever possible, the animals were captured by hand, or by using a rope inserted inside a $2 \mathrm{~m}$ long $3 / 4$ inches thick wall PVC pipe. Captured animals were marked, measured, sexed, and subsequently released. The variables recorded were a) total length, $b$ ) snout-vent lenght, c) tail lenght, d) length of the head, between the back of the cranial table and the tip of the snout. All measurements were made using a tape measure $(+/-0.5 \mathrm{~mm})$ (Bolaños, Sánchez, \& Piedra, 1996-1997). As mentioned, an identification microchip or tag was placed in the groin of the left paw, as well as the amputation of the caudal scales for its visible marking (Bolton, 1989). In the case of caimans, only the insertion of a microchip in the left groin paw was used. Seven and six size classes were used to classify crocodiles and caimans respectively, with $50 \mathrm{~cm}$ intervals. This classification allows the comparison of the data with those obtained in different censuses carried out in Costa Rica.

\section{Correction to the probability of obser-} vation: The works of counting and observation of sizes were made in the different segments, trying to reach the most hidden places possible; navigation at very low speed, with low horsepower engine, and inflatable boat flat bottom, which made possible the observation practically at water level. Despite these conditions, it is known that one can never be certain how many crocodiles or caimans remained under water long before this visit to the place, and continued there even after the passage. Some could also have been out of the water, in the part of the wetland where it is not possible to enter either by boat or on foot; some others could have been laying in the brush that floats on the banks of the water courses, even the event of a recent flood could affect the observations. In this way, a series of external factors can directly or indirectly affect the results of the counts and observations (King, Espinal, \& Cerrato, 1990; Escobedo, 2003); when these external factors can directly or indirectly affect the results of counts and observations, they provide the way to estimate the real percentage of sightings, supported by Messel, Vorlicek, Wells and Green (1981), calculating what they called "visible fraction" or " $p$ ", which is interpreted as the probability of observing crocodilians during counts. This visible fraction can be calculated as:

$$
\mathrm{p}=1-\left(\mathrm{s}^{2} / \mathrm{m}\right)
$$

Where: $\mathrm{p}=$ fraction of crocodilians observed during a survey or sampling; $\mathrm{s}=$ standard deviation of the totals; $\mathrm{m}=$ average value of counts.

A visible fraction " $p$ " will be calculated for both crocodiles and caimans.

If the visible fraction offers a negative result, which is incompatible with a binomial distribution, this is clearly owed to the fact that the surveys performed yield high variations in relation to their respective mean. This would be possible when there are extreme values in the data series, very high counts, contrasting in different realizations of the recognitions; which can happen with only visiting the field in different environmental conditions, or that a traumatic event had happened during the period between surveys that induce inward movements or vice versa in the corresponding habitat.

In this condition, the distribution of the sightings can not be assumed as binomial to make the estimates, but it is possible to correct the calculation by approaching a normal distribution calculating a correction factor (Messel, Vorlicek, Wells, \& Green, 1981), if can be reasonably assumed that the distribution of crocodilians in the study área, is normal or approaches to it in terms of the crocodilians sight counts, or it is at least symmetric. If this happens to be the case, the correction fraction can be calculated as:

$$
\mathrm{p}=\mathrm{x} /((2 \mathrm{x}+\mathrm{s}) * 1.05)
$$

Where $\mathrm{x}$ and $\mathrm{s}$ stand respectively for the mean and standard deviation of the whole 
study, and 1.05 as error. Then the estimated population will come from the cocient of:

$$
\mathrm{N}=100 / \mathrm{p}
$$

Given that in previous studies performed in other localities, caimans and crocodiles had shown to appear somehow grouped during the counts, in order to determine if this is really the case, in this study individuals were assumed "grouped" if they were found at distances less than 50 linear meters from other conspecifics, and a number " 1 " was asigned to those observations; otherwise they were given a number " 2 " and they were considered "scattered".

For the statistical analysis it was used Statistical Package for the Social Sciences, SPSS Version 22 (IBM Corp, 2013).

\section{RESULTS}

It was found that only $5 \%$ of the observed crocodilians were sighted outside the water, and never more than $3 \mathrm{~m}$ away from the water line. The juvenile and subadult caiman, size classes II and III $(0.5<\mathrm{X} \leq 1.5 \mathrm{~m})$ were spotted indistinctly both on margins with plant cover and on edges lacking it. Adult caimans, size classes IV and V $(\mathrm{X}>1.5 \mathrm{~m})$ were found in open-edge areas, or shores with abundant presence of trees or tree branches, while recruit caimans, size class I $(0 \leq X \leq 0.5 \mathrm{~m})$ were always located on the edges that have large masses of grasses and other aquatic plants, such as lily (Eichhornia crassipes) and water lettuce (Pistia stratiotes).

Crocodiles behave similar to caimans, with subadults and adults $(\mathrm{X}>2 \mathrm{~m})$ found in waters with greater flow, while the smaller sizes, neonates, recruits and juveniles $(\mathrm{X} \leq 2 \mathrm{~m})$ were observed on edges both open and covered by vegetation. C. acutus, was observed in general in open areas, especially in places where there were small beaches or dams in the water courses, also the mouth of rivers in the sea are known for the sighting of crocodiles. Usually, larger animals were found in the middle of the river.
Sight counts and population structure: Table 1 shows the counting of caimans in the study area, highlighting the Caño BlancoParismina segment with 68 individuals in total, as well as segments in the Reventazón and all the Matina rivers, with low densities, between 6 and 7 individuals in total and the Caldera lagoon with 4 .

On the other hand, crocodiles were sighted especially in the segments Matina river (66 individuals) and Laguna Jalova (10 individuals); Pacuare river in its upper part presents some sporadic sightings. In the Reventazón River, it was possible to observe crocodiles of smaller sizes of no more than $2 \mathrm{~m}$, and very few larger ones with sizes of more than $2 \mathrm{~m}$; in the same way, some scattered specimens were seen in Caño California (Table 2).

Among the observations there is an average count of 20 individuals that were not registered, since it was not possible to estimate the size or determine the species of the organisms, since they submerged before a proper visualization. They were considered in the accounting strictly to keep track of the total number of crocodilians sighted, without knowing neither their species nor their size class.

The calculus of the visible fraction according to formula numbered as " 1 ", provided the negative results of -2.510 and -3.457 for caimans and crocodiles respectively; in such a case, formula "2" can still be used. To the interest of our case, Kolmogorov-Smirnov test for normality do not allow to accept the null hypothesis of normal distribution; nevertheless, Dickinson (1976) states that the assumption of normality becomes more important when the sample size is small $(\mathrm{n} \leq 50)$, and that every distribution will tend to normal as the sample size increases. We have a sample size $\mathrm{n}=757$, and besides, our distribution has a rather acceptable skewness coefficient of Skp $=0.567$, and an almost normal kurtosis coefficient of $\mathrm{k}=0.283$ (Chou, 1977). All these three conditions provide support enough to proceed assuming normality to recalculate the data aided by Messell's formula, instead of 
TABLE 1

Sighting counts of caimans in the Central Caribbean

\begin{tabular}{|c|c|c|c|c|c|c|c|c|}
\hline \multirow{2}{*}{$\begin{array}{c}\text { Rep Segment } \\
\quad \text { Size class } \rightarrow\end{array}$} & \multirow[t]{2}{*}{$\mathrm{Km}$} & \multirow{2}{*}{$\begin{array}{l}\text { Recruit } \\
\text { I }\end{array}$} & \multirow{2}{*}{$\begin{array}{c}\text { Juvenile } \\
\text { II }\end{array}$} & \multirow{2}{*}{$\begin{array}{c}\text { Sub-adult } \\
\text { III }\end{array}$} & \multicolumn{3}{|c|}{ Adult } & \multirow{2}{*}{ Tota } \\
\hline & & & & & IV & $\mathrm{V}$ & VI & \\
\hline 1 Reventazón river & 29 & & 10 & 6 & & 1 & & 17 \\
\hline 2 Reventazón river & 29 & & 2 & 1 & 3 & & & 6 \\
\hline 3 Reventazón river & 29 & 1 & 4 & 8 & 1 & 1 & & 15 \\
\hline 1 Pacuare river & 17 & & 18 & 2 & & & & 20 \\
\hline 2 Pacuare river & 17 & & 4 & 7 & 5 & & & 16 \\
\hline 3 Pacuare river & 17 & & 6 & 6 & 3 & & & 15 \\
\hline 1 Matina river & 25 & 3 & 3 & 1 & & & & 7 \\
\hline 2 Matina river & 25 & 6 & 1 & & & & & 7 \\
\hline 3 Matina river & 25 & 4 & 3 & 2 & & & & 9 \\
\hline 1 Jalova Lagoon & 2.2 & & 4 & 1 & & & & 5 \\
\hline 2 Jalova Lagoon & 2.2 & & 3 & 4 & 1 & & & 8 \\
\hline 3 Jalova Lagoon & 2.2 & & 4 & 3 & & & & 7 \\
\hline 1 Caño California & 6.5 & 22 & 5 & & 1 & 1 & 2 & 31 \\
\hline 2 Caño California & 6.5 & 14 & 11 & 4 & 2 & 2 & 2 & 35 \\
\hline 1 Channel Jalova- Rev. & 5.8 & 3 & 25 & 2 & 2 & & & 32 \\
\hline 2 Channel Jalova- Rev. & 5.8 & 1 & 20 & 8 & 4 & 1 & & 34 \\
\hline 1 Caño Pascual & 6.5 & 15 & 9 & 1 & & & & 25 \\
\hline 2 Caño Pascual & 6.5 & 18 & 7 & 3 & 2 & & & 30 \\
\hline 1 Caño Blanco-Parismina & 5.5 & 3 & 17 & 2 & 1 & 1 & & 24 \\
\hline 2 Caño Blanco-Parismina & 5.5 & 21 & 25 & 16 & 4 & 2 & & 68 \\
\hline 1 Channel Pacuare-Rev. & 8.5 & & 10 & 21 & 9 & 1 & & 41 \\
\hline 2 Channel Pacuare-Rev. & 8.5 & & 14 & 8 & 2 & & & 24 \\
\hline 1 Channel Pacuare-Mat. & 13.75 & 4 & 18 & 28 & 6 & 1 & & 57 \\
\hline 2 Channel Pacuare-Mat. & 13.75 & 2 & 21 & 15 & 5 & 1 & & 44 \\
\hline 1 Caldera Lagoon & 3 & 1 & 1 & 1 & 1 & & & 4 \\
\hline 1 Caño Chiquero & 1.2 & 3 & 6 & 2 & & & & 11 \\
\hline 1 Perla Lagoon & 1.7 & & & 6 & & & & 6 \\
\hline TOTAL & 113.35 & 121 & 251 & 158 & 52 & 12 & 4 & 598 \\
\hline
\end{tabular}

For segment by total length, 2017.

transforming the data searching for the compliance of the requirements.

This yields the result of $p=26.65 /$ $((2 * 9.67+26.65) * 1.05)$, and $\mathrm{p}=0.55$, to a Correction Factor CF: $1 / \mathrm{p}=1 / 0.552=1.811$ for caimans; and $\mathrm{p}=16.03 /((2 * 8.45+16.03) * 1.05)$ and $\mathrm{p}=0.46$, to a $\mathrm{CF}: 1 / \mathrm{p}=1 / 0.46=2.16$ for crocodiles. Procedure is shown on Table 3 and Table 4. The sight counts corrected are presented in Table 5 and Table 6. As shown in figure 4 for crocodiles and caimans, both species present a positive right slightly biased distribution, with a high number of observations in the intermediate classes and little or none in the larger sizes of the classification (Fig. 4).

To the average number of crocodilians, should be added the number of indeterminated organisms, proportionally distributed by species as 26 for caimans and 12 for crocodiles, which leaves the population totals as 1110 caimans and 515 crocodiles.

Table 7 shows the number of organisms of both species, along with the number of kilometers in the different segments. It becomes apparent the fact that most caimans inhabit the intercommunicating channels along the coast 
TABLE 2

Sighting counts of crocodiles in the Central Caribbean

\begin{tabular}{|c|c|c|c|c|c|c|c|c|}
\hline \multirow{2}{*}{$\begin{array}{l}\text { Rep Segment } \downarrow \\
\text { Size class } \rightarrow\end{array}$} & \multirow{2}{*}{$\begin{array}{c}\text { Newborn } \\
\text { I }\end{array}$} & \multirow{2}{*}{$\begin{array}{c}\text { Recruit } \\
\text { II }\end{array}$} & \multicolumn{2}{|c|}{ Juvenile } & \multicolumn{2}{|c|}{ Sub-adult } & \multirow{2}{*}{$\begin{array}{l}\text { Adult } \\
\text { VII }\end{array}$} & \multirow{2}{*}{ Total } \\
\hline & & & III & IV & V & VI & & \\
\hline 1 Reventazón & 1 & 5 & 1 & & & 1 & & 8 \\
\hline 2 Reventazón & 10 & 4 & 3 & & & & & 17 \\
\hline 3 Reventazón & 2 & 2 & 1 & 1 & & 1 & & 7 \\
\hline 1 Pacuare & & 1 & 2 & & & & & 3 \\
\hline 2 Pacuare & & & 1 & & & & & 1 \\
\hline 3 Pacuare & & 4 & 4 & 2 & & & & 10 \\
\hline 1 Matina & 3 & 30 & 9 & 10 & 6 & 8 & & 66 \\
\hline 2 Matina & 3 & 16 & 9 & 3 & 3 & & & 34 \\
\hline 3 Matina & 4 & 22 & 9 & 7 & 4 & 3 & & 49 \\
\hline 1 Jalova Lagoon & 1 & 2 & & & & & 1 & 4 \\
\hline 2 Jalova Lagoon & & 7 & & 1 & & & 1 & 9 \\
\hline 3 Jalova Lagoon & & 5 & & 2 & 1 & & 2 & 10 \\
\hline 1 Caño California & & 1 & 2 & & 1 & 2 & & 6 \\
\hline 2 Caño California & & 3 & 3 & 1 & 1 & 1 & & 9 \\
\hline TOTAL & 24 & 102 & 44 & 27 & 16 & 16 & 4 & 233 \\
\hline
\end{tabular}

For segment by total length, 2017.

TABLE 3

Mean and standard deviation of the observation of caimans per segment

\begin{tabular}{lcccccc}
\multicolumn{1}{c}{ Segment } & $\mathrm{n}$ & Mean & St. Dev. & Var. & $\mathrm{n}-1$ & $($ Var)*(n-1) \\
Reventazón river & 3 & 12.67 & 5.86 & 34.33 & 2 & 68.67 \\
Pacuare river & 3 & 17.00 & 2.65 & 7.00 & 2 & 14.00 \\
Matina river & 3 & 7.67 & 1.16 & 1.33 & 2 & 2.67 \\
Jalova lagoon & 3 & 6.67 & 1.53 & 2.33 & 2 & 4.67 \\
Caño California & 2 & 33.00 & 2.83 & 8.00 & 1 & 8.00 \\
Channel Jalova-Reventazón & 2 & 33.00 & 1.41 & 2.00 & 1 & 2.00 \\
Caño Pascual & 2 & 27.50 & 3.54 & 12.50 & 1 & 12.50 \\
Caño Blanco-Parismina & 2 & 46.00 & 31.11 & 968.00 & 1 & 968.00 \\
Channel Pacuare-Reventazón & 2 & 32.50 & 12.02 & 144.50 & 1 & 144.50 \\
Channel Pacuare-Matina & 2 & 50.50 & 9.19 & 84.50 & 1 & 84.50 \\
& 24 & 266.50 & & & 14 & 1309.50 \\
\hline
\end{tabular}

TABLE 4

Mean and standard deviation of the observation of crocodiles per segment

\begin{tabular}{lcccccc}
\multicolumn{1}{c}{ Segment } & N & Mean & St. Dev. & Var. & n-1 & $($ Var)*(n-1) \\
Reventazón river & 3 & 10.67 & 5.51 & 30.33 & 2 & 60.67 \\
Pacuare river & 3 & 4.67 & 4.73 & 22.33 & 2 & 44.67 \\
Matina river & 3 & 49.67 & 16.01 & 256.33 & 2 & 512.67 \\
Jalova lagoon & 3 & 7.67 & 3.22 & 10.33 & 2 & 20.67 \\
Caño California & 2 & 7.50 & 2.12 & 4.50 & 1 & 4.50 \\
& 14 & 80.17 & & & 9 & 643.17 \\
\hline
\end{tabular}


TABLE 5

Estimated counting of caimans in the Central Caribbean

\begin{tabular}{|c|c|c|c|c|c|c|c|}
\hline $\begin{array}{ll}\text { Segment } & \downarrow \\
\text { Size class } & \rightarrow\end{array}$ & $\begin{array}{c}\text { Recruit } \\
\text { I }\end{array}$ & $\begin{array}{c}\text { Juvenile } \\
\text { II }\end{array}$ & $\begin{array}{l}\text { Sub-adult } \\
\text { III }\end{array}$ & $\begin{array}{c}\text { Sub-adult } \\
\text { IV }\end{array}$ & $\begin{array}{l}\text { Adult } \\
\text { V }\end{array}$ & $\begin{array}{c}\text { Adult } \\
\text { VI }\end{array}$ & Total \\
\hline Reventazón river & 2 & 29 & 27 & 7 & 4 & & 69 \\
\hline Pacuare river & & 51 & 27 & 15 & & & 92 \\
\hline Matina river & 24 & 13 & 5 & & & & 42 \\
\hline Jalova Lagoon & & 20 & 15 & 2 & & & 36 \\
\hline Caño California & 65 & 29 & 7 & 5 & 5 & 7 & 120 \\
\hline Channel Jalova-Rev. & 7 & 82 & 18 & 11 & 2 & & 120 \\
\hline Caño Pascual & 60 & 29 & 7 & 4 & & & 100 \\
\hline Caño Blanco-Parismina & 44 & 76 & 33 & 9 & 5 & & 167 \\
\hline Channel Pacuare-Rev. & & 44 & 53 & 20 & 2 & & 118 \\
\hline Channel Pacuare-Matina & 11 & 71 & 78 & 20 & 4 & & 183 \\
\hline Caldera Lagoon & 2 & 2 & 2 & 2 & & & 7 \\
\hline Caño Chiquero & 5 & 11 & 4 & & & & 20 \\
\hline Perla Lagoon & & & 11 & & & & 11 \\
\hline Total & 219 & 455 & 286 & 94 & 22 & 7 & 1084 \\
\hline
\end{tabular}

For segment by total length, 2017.

TABLE 6

Estimated counting of crocodiles in the Central Caribbean

\begin{tabular}{|c|c|c|c|c|c|c|c|c|c|}
\hline Segment & $\downarrow$ & Newborn & Recruit & Juv. & Juv. & Sub-adult & Sub-adult & Adult & Total \\
\hline Siza class $\rightarrow$ & & I & II & III & IV & $\mathrm{V}$ & VI & VII & \\
\hline Reventazón & & 29 & 25 & 11 & 2 & & 5 & & 72 \\
\hline Pacuare & & & 11 & 16 & 5 & & & & 32 \\
\hline Matina & & 23 & 131 & 61 & 45 & 29 & 25 & & 314 \\
\hline Laguna Jalova & & 2 & 32 & & 7 & 2 & & 9 & 52 \\
\hline Caño Calif. & & & 9 & 11 & 2 & 5 & 7 & & 34 \\
\hline Total & & 54 & 208 & 99 & 61 & 36 & 36 & 9 & 503 \\
\hline
\end{tabular}

For segment by total length, 2017.

line, which intercommunicate the rivers; as well as the segment Caño Blanco-Parismina, wich is really a communicating segment between the channels Pacuare-Reventazon and Parismina-Jalova.

The presence of both species in the different studied segments, turned out to be significantly different for crocodiles and for caimans (Kruskal-Wallis, $\mathrm{X}^{2}=355.7, \mathrm{gl}=12, \mathrm{P} \leq$ 0.000 ). Likewise, the size distribution is similar for crocodiles reported in all environments (Kruskal-Wallis, $\mathrm{X}^{2}=8.12$, gl $=5, \mathrm{P} \leq 0.15$ ), while for caimans it indicates that there is a different distribution for sizes, according to the environment in which they are found (Kruskal -Wallis, $\mathrm{X}^{2}=63.87, \mathrm{gl}=12, \mathrm{P} \leq 0.000$ ), with a bias against of the Pacuare and Matina rivers.

Based on the catches made, it was estimated a sex ratio of 1.25 and 0.83 males to females, in crocodiles and caimans respectively, with 9 and 11 captures in that same order, in individuals of recruits, juvenile and subadult sizes.

The sight count per segment shows sites with values of up to 183 recorded caimans (Pacuare-Matina channel). For crocodiles, the Matina River has the highest number of recorded individuals (139) and Pacuare shows 


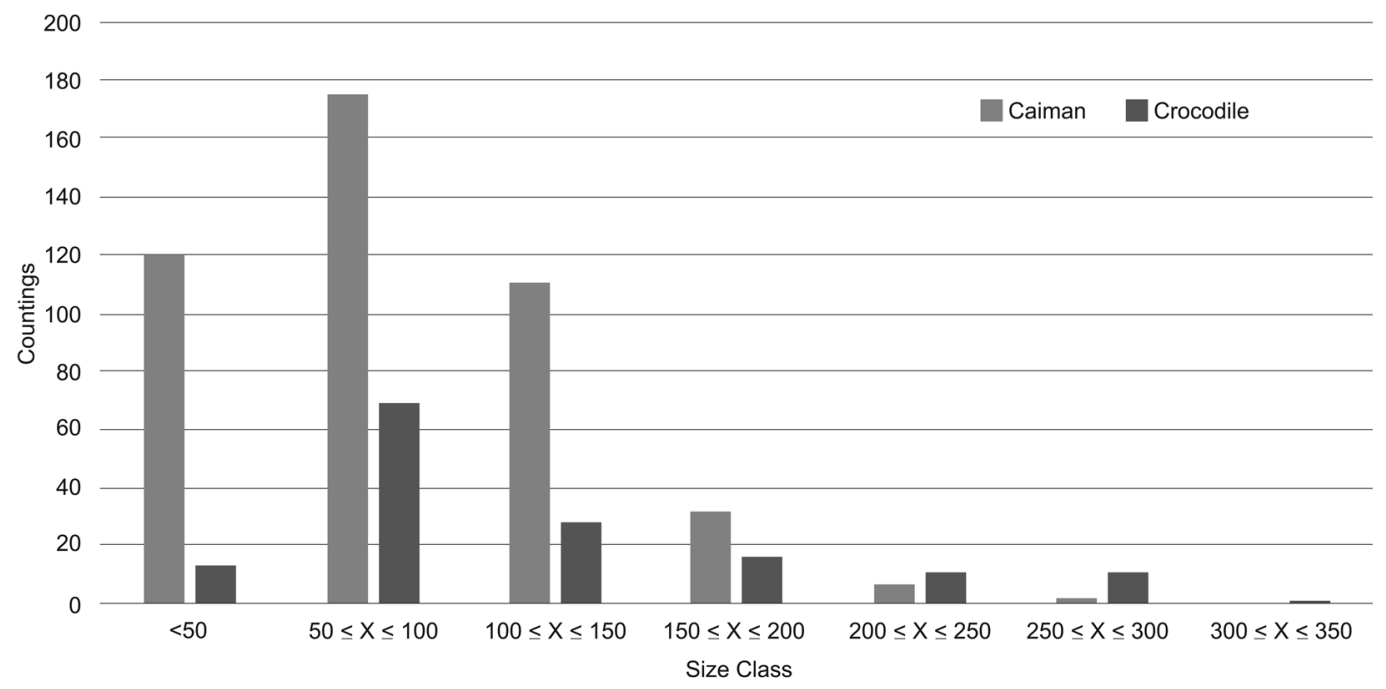

Fig. 4. Crocodilian distribution by size according to species.

TABLE 7

Sight count numbers for segment by species

\begin{tabular}{lccccc}
\multicolumn{1}{c}{ Segment } & $\mathrm{km}$ & crocodiles & crocodiles & caimans & caimans \\
& & Count & $\# / \mathrm{km}$ & count & $\# / \mathrm{km}$ \\
Reventazón river & 29 & 32 & 1.10 & 69 & 2.38 \\
Pacuare river & 17 & 14 & 0.82 & 92 & 5.44 \\
Matina river & 25 & 139 & 5.56 & 42 & 1.67 \\
Jalova Lagoon & 2.2 & 23 & 10.45 & 36 & 16.48 \\
Caño California & 6.5 & 15 & 2.31 & 120 & 18.41 \\
Channel Jalova-Reventazón & 5.8 & & & 120 & 20.63 \\
Caño Pascual & 6.5 & & & 100 & 15.34 \\
Caño Blanco-Parismina & 5.5 & & & 167 & 30.32 \\
Channel Pacuare-Rev. & 8.5 & & & 18 & 13.86 \\
Canal Pacuare-Matina & 13.75 & & & 7 & 13.32 \\
Caldera Lagoon & 3 & & & 20 & 2.42 \\
Caño Chiquero & 1.2 & & & 11 & 16.62 \\
Perla Lagoon & 1.7 & 223 & & & 6.47 \\
TOTAL & 125.65 & & & & 8.63 \\
\hline
\end{tabular}

the least count (14) (Table 7). As mentioned, a high sight count is observed for crocodiles in the segments of Jalova and the Matina River (Kruskal-Wallis, $\mathrm{X}^{2}=18.75, \mathrm{gl}=5, \mathrm{P} \leq 0.001$ ); while caimans show a significantly greater sight count in the coastal Tortuguero canals (Kruskal-Wallis, $\mathrm{X}^{2}=26.09, \mathrm{gl}=12, \mathrm{P} \leq 0.004$ ). The analysis of the grouping of the corresponding observations during the counts, indicates that both crocodiles and caimans appear in the environment in a significantly grouped manner (Runs test, $\mathrm{Z}=3.62, \mathrm{P} \leq 0.001$ ).

\section{DISCUSSION}

The fact that the distribution by size for both species shows a positive bias towards the right, with few observed elements of its smaller 
size classes, a high number in the intermediate classes and little or none of the elements in the larger sizes of the classification, except for the observation made in relation to individuals of higher sizes, is consistent with its selective nature of habitat (Balaguera-Reina \& Gonzalez-Maya, 2009), where large animals avoid contact with humans and their activities, and small ones are kept retired from those places where activities are being held until they reach a proper size. For caimans in the Colombian Caribbean, these same authors have found predominance of individuals of inferior sizes and little or no presence of adult individuals. Contrariwise, the distribution of C. acutus found by Sánchez et al. (1996) in the Tempisque and Bebedero rivers in the Costa Rican Pacific slope, where they found a lot more representatives of the small and large size classes, which we did not in our study; and far distant from further studies in the same area performed by Sánchez (2001) and Bolaños (2012a), with a pronounced increase in the population numbers. These findings call the attention to the different environment matter, joined to the fact that the Pacific slope of the country is a lot more developed than the Caribbean side.

These results launch the speculation that this habitat in the low lands of the Caribbean side, provides a good area for large crocodiles to patrol, hunt and consolidate territory, but a bad place to mate and nest, given that the whole area is exposed to sudden floodings, specially during the months of early winter, when the crocodile nests are still in the field. This characteristic favours the development of the caiman population, whose nests strategy considers this possibility and allow the easy and fast drainage of the nest, and the eggs present a shell structure to deal with the problem as well. On the other hand, it has been observed that, related to crocodiles, they present larger populations in places close to human settlings (Bolaños, 2012a). These conditions seem to lead the conjecture that large crocodiles in the area could be inhabiting in larger numbers in the upper part of the water courses that irrigate the zone, beyond the $25 \mathrm{~km}$ inland limits of this study; the rivers Raventazón, Chirripó Atlántico, and Pacuare.

The Matina River and the Jalova Lagoon are the two main sites for the observation of crocodiles in the Caribbean, it's abundance of $1.77 \mathrm{ind} / \mathrm{km}$ is a lot lower than those reported by Sánchez et al. (1996) of $18.6 \mathrm{ind} / \mathrm{km}$, and Orozco (2015) of 11.7 for the Tempisque river, in the North Pacific of Costa Rica, in whereas caimans, with a more homogeneous distribution throughout the sampling area, showed a density of $8.63 \mathrm{ind} / \mathrm{km}$, considerably more than that reported by King et al. (1990) for Honduras, of 2.2 individuals per kilometer in a similar environment to the one being studied, but lower than the 12.5 reported by Bolaños et al. (1996) for La Rambla de Sarapiquí, in the Northern Zone of Costa Rica. On the other hand, Balaguera-Reina and Gonzalez-Maya (2009) report numbers as low as $0.063 \mathrm{ind} / \mathrm{ha}$ in terms of density, but which they indicate are normal for environments under exploitation. It is also interesting how $54 \%$ of all the caimans, belong to those segments which could be called "the boat transit" passage, (Matina-Pacuare Channel, Pacuare-Reventazón Channel, Caño Blanco-Parismina, and Jaloba-Reventazón Channel); calling the attention to somehow think that they could be preferring to inhabit places where man use to have activities.

The population of caimans found, presents estimated numbers consistent with what was expected for the environmental characteristics of the area and for the size of the study area, underlining that it was not possible to observe the high component of the size classification, which consists of adult reproductive individuals size class III ( $\geq 1.5 \mathrm{~m}$ ). However, the habitat conditions allow to speculate that these adult caimans, could remain hidden in the inner part of the wetland, in deposits and watercourses internal and inaccessible to the eye of the researcher, especially females and neonates (Bolaños et al., 1996-1997; Da Silveira, Magnusson, \& Campos, 1997).

Unlike caimans, the quantity and size structure of the crocodiles observed did not come close to what was expected, considering 
existing populations under similar environmental conditions (De Sola, Velasco, Villaroel, \& Colomine, 2004; Bolaños, 2012a; Murray et al., 2015). In this case, apart from the Matina River, the Caño California and Boca de Jalova, the crocodile is evidently absent in the whole area studied, with special mention to individuals with sizes greater than size class VI $(\geq 3$ $\mathrm{m})$, different from that found by Sánchez et al. (1996), Bolaños (2012b) and Orozco (2015) for the Pacific.

It was observed during this study, that there is a different distribution of the crocodiles in the landscape, which seems to sketch preference for water courses with a rocky bottom, although in this study has not been proven the cause-effect condition related to the presence or absence of crocodiles in a certain area; nevertheless, the conditions are consistent with what was suggested by Carvajal, Saavedra and Alava (2005). The previous situation could be due to the fact that the entire study area is a floodplain, with less than $15 \mathrm{~m}$ above sea level in its highest sector (Herrera \& Mata, 1993; Brenes, 2016; INDER, 2016), it is possible that larger breeding individuals prefer to locate permanently in an area that is not subject to sudden climatic changes, which allows them to position their nests without the risk of losing the eggs as a result of floods, which are characteristic in the study area during a period of at least 6 months every year (Kushlan \& Mazzotti, 1986).

On the other hand, although both species are sympatric and share the environment and available resources, they certainly did never appear together during field observations, and both exhibit gregarious behavior. In the case of caimans, the groups are composed of individuals of different sizes, in what apparently represent family groups (Bolaños et al., 1996-1997; Venegas-Anaya et al., 2015); while speaking of crocodiles, although it is true that in the groups some individuals of dissimilar sizes may appear, the composition observed in the groups was of individuals of the same size, in what was interpreted as member of the same cohort, wether they were parentaly related or not.

Ethical statement: authors declare that they all agree with this publication and made significant contributions; that there is no conflict of interest of any kind; and that we followed all pertinent ethical and legal procedures and requirements. All financial sources are fully and clearly stated in the acknowledgements section. A signed document has been filed in the journal archives.

\section{ACKNOWLEDGMENTS}

Thanks to the Dallas World Aquarium Zoo for the support that allowed to achieve the objectives of this research.

\section{RESUMEN}

Estado de la población del cocodrilo americano, Crocodylus acutus (Reptilia: Crocodilidae) y el caimán, Caiman crocodilus (Reptilia: Alligatoridae), en el Caribe central de Costa Rica. Dos especies de cocodrilianos han sido descritas en Costa Rica, el cocodrilo americano, Crocodylus acutus (Cuvier, 1807) y el caimán, Caiman crocodilus (Linnaeus, 1758). En Costa Rica se ha generado información de ambas especies, pero con énfasis en la vertiente del Pacífico, presumiblemente debido a su mayor desarrollo, lo cual ha acarreado mayor presión social hacia la atención de incidentes generados por el encuentro entre humanos y cocodrilos. El estudio se desarrolló durante el 2017 y en un área de aproximadamente $400 \mathrm{~km}^{2}$, caracterizada por tener una amplia densidad de cursos de agua que incluyen a los ríos: Matina, Pacuare, Reventazon y Parismina. En estos ríos se recorrió un promedio de $25 \mathrm{~km}$ desde la línea de costa hasta el interior del territorio, incluyendo los canales de Tortuguero, así como otros cuerpos de agua que conectan a estos ríos, lagunas importantes, y canales secundarios. Se realizaron tres repeticiones por segmento. Una población de 1084 caimanes y 503 cocodrilos fue estimada, para una abundancia relativa de 8.64 y $2.80 \mathrm{ind} / \mathrm{km}$ respectivamente. Con respecto a caimanes poco más del $12 \%$ de los animales observados estaban en edad reproductiva, mientras que para cocodrilos sólo un 2 $\%$. La abundancia en los diferentes segmentos resultó ser significativamente diferente para ambas especies (KruskalWallis, $\mathrm{P} \leq 0.000)$. Mientras que la distribución por tallas de cocodrilos fue similar en todos los segmento (KruskalWallis, $\mathrm{P} \leq 0.15$ ). Con 9 cocodrilos y 18 caimanes, reclutas o juveniles capturados, se calculó una proporción de sexos 
de 1.25 y 0.83 machos a hembras, para cocodrilos y caimanes respectivamente.

Palabras clave: Crocodylus acutus, Caiman crocodilus, Costa Rica, Caribe Central, estado poblacional de cocodrilianos, Canales de Tortuguero.

\section{REFERENCES}

Allsteadt, J., \& Vaughan, C. (1988). Ecological studies of the central american caiman (Caiman crocodilus fuscus) en Caño Negro Refugio Nacional de Vida Silvestre, Costa Rica. Herpetological Society, 23, 123-126.

Balaguera-Reina, S., \& González-Maya, J. (2009). Estructura poblacional, abundancia, distribución y uso de hábitat de Caiman crocodilus fuscus (Cope, 1868) en la Vía Parque Isla Salamanca, Caribe colombiano. Revista de Biología Marina y Oceanografia, 44(1), 145-152.

Bolaños, J. (2011a). Plan estratégico para el manejo de la población de Crocodylus acutus (cocodrilo Americano) en el Gran Humedal del Tempisque. San José, Costa Rica: SINAC.

Bolaños, J. (2011b). Propuesta plan de contingencia en el manejo de la población de cocodrilos del Gran Humedal del Tempisque. San José, Costa Rica: SINAC.

Bolaños, J. (2012a). Population status of the American crocodile (Crocodylus acutus) in the Tempisque Great Wetland. In 21st Working Meeting of the IUCN-SSCCrocodile Specialist Group (pp. 167-178). Manila, Filipinas.

Bolaños, J. (2012b). Survey of American crocodiles in Tempisque Great Wetlands, Guanacaste, Costa Rica. Crocodile Specialist Group Newsletter, 31(1), 2-7.

Bolaños, J., Sánchez, J., \& Piedra, L. (1996-1997). Inventario y estructura poblacional de crocodílidos en tres zonas de Costa Rica. Revista de Biología Tropical, 33(3)/45(1), 283-287.

Bolton, M. (1989). The management of crocodiles in captivity. Roma, Italy: FAO.

Brenes, A. (2016). Gestión del riesgo y vulnerabilidad en Costa Rica. San José, Costa Rica: Vigésimo segundo informe estado de la nación en desarrollo humano sostenible

Carvajal, R., Saavedra, M., \& Alava, J. (2005). Population ecology, distribution and habitat assessment of Crocodylus acutus (Cuvier, 1807) in the Reserva de producción de fauna manglares El Salado of the Guayaquil estuary, Ecuador. Revista de Biología Marina y Oceanografia, 40(2), 133-140.
Chou, Y. L. (1977). Análisis estadístico. Mexico: Nueva Editorial Interamericana S.A.

Da Silveira, R., Magnusson, W., \& Campos, Z. (1997). Monitoring the distribution, abundance and breeding areas of Caiman crocodilus crocodilus and Melanosuchus niger in the Anavilhanas archipiélago, Central Amazonia, Brasil. Herpetological Journal, 31, 514-520.

De Sola, R., Velasco, A., Villaroel, G., \& Colomine, G. (2004). Evaluation of wild populations and habitats of the american crocodile (Crocodylus acutus) in Venezuela. In Proceedings of the 17th Working Meeting of the IUCN-SSC-Crocodile Specialist Group (pp. 248-256). Darwin, Australia.

Dickinson, J. (1976). Nonparametric methods for quantitative analysis. Ohio, USA: American Sciences press Inc.

Escobedo, A. (2003). Periodos de actividad y efectos de las variables ambientales en cocodrilos (Crocodylus acutus Cuvier 1807): evaluando los métodos de determinación de la fracción visible. Ecología aplicada, 2(1), 136-140.

Herrera, V., \& Mata, R. (1993). Cartografía y clasificación de los suelos de la llanura aluvial delimitada por los ríos Madre de Dios, Barbilla y Matina. Agronomía Costarricense, 17(1), 7-24.

IBM Corp. (2013). Statistical Package for the Social Sciences, SPSS (Version 22). New York, USA. Retrieved from https://ibm-spss-statistics-base.en.uptodown. com/windows

INDER. (2016). Caracterización del territorio LimónMatina. Limón, Costa Rica: Dirección Huetar Caribe - INDER.

King, F., Espinal, M., \& Cerrato, C. (1990). Distribution and status of the crocodilian of Honduras. Results of a survey conducted for the Convention of International Trade in Endangered Species of Wild Fauna and Flora, and the Honduras Secretaría de Recursos Renovables. In Proceedings of the 10th Working Meeting of the Crocodile Specialist Groupof the Species Survival Commission of IUCN (pp. 313-354). Florida, USA.

Kushlan, J., \& Mazzoti, F. (1986). Population biology and status of the American crocodile in South Florida. Florida, USA: Unión Internacional para la Conservación de la Naturaleza.

Levy, C. (1981). Endangered Species: Crocodiles and Alligators. Nueva Jersey, USA: Chartwell Books.

Messel, H., Vorlicek, G., Wells, A., \& Green, W. (1981). Surveys of the tidal river system in Northern Territory of Australia and their crocodile populations. Sydney, Australia: Pergamon. 
Murray, C., Easter, M., Padilla, S., Garrigós, D., Stone, J., Bolaños-Montero, J., . . . Guyer, C. (2015). Cohortdependent sex ratio biases in the American crocodiles (Crocodylus acutus) of the Tempisque basin. Copeia, 103(3), 241-545.

Orozco, W. (2015). Monitoreo de la población de cocodrilos en la cuenca baja del río Tempisque. Guanacaste. Costa Rica. Liberia, Guanacaste, Costa Rica (Tesis Licenciatura). Universidad Técnica Nacional, Costa Rica.

Piedra, L. (2000). Población de cocodrilos (Crocodylus acutus) en tres ríos del Pacífico Central de Costa Rica (Tesis Licenciatura). Universidad Nacional, Costa Rica.

Ross, J. (1998). Crocodiles. Gland, Suiza: IUCN, SSC, Crocodile Specialist Group.

Sánchez, G. (1991). Estimación preliminar de la población de Caiman crocodilus fuscus en la época seca en el Refugio Nacional de Vida Silvestre Caño Negro, Alajuela, Costa Rica (Investigación por tutoría). Universidad Nacional, Costa Rica.

Sánchez, J. (2001). Estado de la población de cocodrilos (Crocodylus acutus) en el río Tempisque, Guanacaste. San José, Costa Rica: InBio.

Sánchez, J., Bolaños, J., \& Piedra, L. (1996). Población de Crocodylus acutus (Crocodylia: Crocodilidae) en dos ríos de Costa Rica. Revista de Biología Tropical, 44(2), 835-840.
Sandoval-Hernández, I., Durán-Apuy, A., \& Quirós-Valerio, J. (2017). Activities that may influence the risk of crocodile (Crocodylus acutus) attack to humans in the Tempisque river area, Guanacaste, Costa Rica. Uniciencia, 31(1), 13-22.

Sasa, M., \& Chaves, G. (1992). Tamaño, estructura y distribución de una población de Crocodylus acutus (Crocodylia: Crocodilidae) en Costa Rica. Revista de Biología Tropical, 40, 131-134.

Torrealba, I., Paz, O., \& Motte, M. (1992). Censo de cocodrilos (Crocodylus acutus) en el rio Grande de Tárcoles, Costa Rica. Heredia, Costa Rica: Aportes al conocimiento de la vida silvestre en el caso de la Reserva Biológica Carara y la Reserva de Manglares Guacalillo.

Valdelomar, V., Ramírez-Vargas, M., Quesada-Acuña, S., Arrieta, C., Carranza, I., Ruiz-Morales, G., \& Espinoza-Bolaños, S. (2012). Percepción y conocimiento popular sobre el cocodrilo (Crocodylus acutus) (Reptilia: Crocodylidae) en zonas aledañas al río Tempisque, Guanacaste, Costa Rica. Cuadernos de Investigación UNED, 4(2), 191-202.

Venegas-Anaya, M., Escobedo-Galván, A., BalagueraReina, S., Lowrance, F., Sanjur, O., \& DensmoreIII, L. (2015). Population ecology of American crocodile (Crocodylus acutus) in Coiba National park, Panamá. Journal of Herpetology, 49, 349-357. 